\title{
Pharmaceutico-analytical profile of Mrityunjay Rasa and evaluation of its Antibacterial activity
}

\author{
Research Article
}

\author{
Swapnali N Khabade1 ${ }^{*}$, Bharat Rathi ${ }^{2}$, Renu Rathi ${ }^{3}$, Rajkumar Gupta ${ }^{4}$ \\ 1. PhD Scholar, Assistant Professor, 2. Professor, 4. Professor, Department of Rasashastra \& Bhaishajya Kalpana, \\ 3. Professor, Department of Kaumarbhritya, \\ Mahatma Gandhi Ayurveda College Hospital \& Research Centre, Salod (H) Wardha (MS) - 442001.
}

\begin{abstract}
Background: Mrityunjay Rasa is the one of the Kharaliya Kalpana explained in Yogaratnakara in Jwara chikitsa and indicated in all types of fever. Any pathology can leads to diseases which are easily seen by fever as a clinical symptom. Bacterial infections through the skin or by any system defiantly reflect through fever and as told in classics Mrityunjay Rasa is having the capacity to eradicate all types of Jwara. Aim \& Objective: The study is planned to evaluate the antibacterial activity of Mrityunjay Rasa. Material and methods: Mrityunjay rasa was prepared according to Yogratnakar at the Department of Rasashastra \& Bhaishajya Kalpana. The formulation was tested for organoleptic characters, physicochemical parameters and microbial specification tests. Observation and results: Standard Mrityunjay rasa can be prepared from three Bhawana of Ardraka swarasa each for an average of 11.55 hrs. Prepared Mrityunjay rasa was Reddish in color with a specific smell and $145.57 \%$ average yield. Analytical standards for Mrityunjay rasa such as loss on drying at $105^{\circ} \mathrm{C}$, total ash, acid insoluble ash, alcohol soluble extractives, water-soluble extractive, $\mathrm{pH}$, Hardness, Disintegration time and particle size were $2.10 \%$, $15.87 \%, 2.43 \%, 2.29 \%, 20.43 \%, 8.7$ (10\% aqueous solution), 3, 30 minutes $20 \mathrm{sec}$ and 95.41 respectively. Mrityunjay Rasa has shown a better zone of inhibition against Staphylococcus aureus. Conclusion: Analytical parameters obtained through the present study can be considered as a reference standard for Mrityunjay rasa.
\end{abstract}

Key Words: Mrityunjay rasa, Pharmaceutical \& Analytical evaluation, Antibacterial study.

\section{Introduction}

Herbo-mineral formulations hold a significant place in Ayurvedic pharmaceutics. Nearly $70 \%$ of formulations include a combination of one or more metallic/mineral with several herbs which have a supporting role in improving efficacy, relieving symptoms of the disease and to achieve long and healthy life (1-2). Herbomineral formulations are distinguished based on various processes performed on raw drugs and termed as Kharaliya, Parpati, Kupipakva and Pottali Rasayana. Among these Pharmaceutical preparations, Kharaliya Rasayana is the basic and important for all preparations. Mrityunjay Rasa is one of the classical formulations prepared by the Kharaliya method. There are so many preparations under the same heading with different indications. Just like its name Mrityunjay, it also stood as a winner by victory over death. Here Mrityu means death and Jaya means victory and exactly it is applicable for Jwara like the deadliest disease.

Jwara is not only a sign, but a disease affecting body senses and mind, it diminishes the intelligence,

\section{* Corresponding Author:}

\section{Bharat Rathi}

Professor, Dept of Rasashastra \& Bhaishajya Kalpana, Mahatma Gandhi Ayurved College Hospital \& Research Centre Salod(H) Wardha. DMIMS (Deemed to be University), Sawangi (M), Wardha (MS). India. Email Id: bharatrathi174@gmail.com strength, complexion joyfulness and enthusiasm of the sufferer and produces exhaustion, exertion, and unconsciousness and aversion to food also can lead even to death (3). There are so many causes for Jwara. Any pathology can leads to diseases which are easily seen by fever as a clinical symptom. Bacterial infections through the skin or by any system defiantly reflect through fever and as told in classics Mrityunjay Rasa is having the capacity to eradicate all types of Jwara. So, it needs to keep one step ahead by analyzing and experimental study. Hence in this study, an attempt is made to evaluate the antibacterial activity of Mrityunjay Rasa prepared as described in Yogratnakar(4).

\section{Materials and Methods Material}

Raw drugs were procured from a local Ayurvedic drug dealer. Gandhaka was procured from S. G. Phyto Pharma. PVT. LTD. Kolhapur. Hingula (Cinnabar), Vatsanabha (Aconite), Gandhaka (Sulphur), and Tankan (Sodium pyroborate/Borax) were authenticated as per organoleptic characters and textual parameters. All the herbal drugs were also identified and authenticated by a taxonomist.

\section{Methods}

Shodhana (purification) of the mineral drugs was done according to the textual reference as shown in table no 1. 
Swapnali N Khabade et.al., Pharmaceutico-analytical profile of Mrityunjay Rasa and evaluation of its Antibacterial activity

Table no 1: Shodhana of the mineral drugs of Mrityunjaya rasa (5-8)

S.No. Name of drug

Gandhak Shodhan

2 Hingula Shodhana

3 Vatsanabha Shodhana

4 Tankana Shodhana
Purification Process

Melting in Cow's ghee and pouring in milk.

Processing 7 times with ginger juice

Soaking in Cows urine for 3 days

Sphatika is kept on fire till a

crystalline water get evaporated and it becomes like a

soft white mass.

\section{Preparation of Powdering of ingredients}

Herbal drugs Maricha and Pippali were collected; physical impurities were removed, dried in sunlight and then powdered individually by using a mixer till it turned into a fine powder. Each powder then sieved through mesh no.80, weighed and kept in an airtight container for further process (9) Preparation of Ardraka Swarasa was done in a mixer and squeezed through cloth to obtain the juice. Strong Smell of Ardraka was experienced during procedure.

Table No.2: Ingredients and Quantity of Mrityunjaya Rasa (4)

\begin{tabular}{|l|l|l|l|l|l|l|}
\hline Sr. no & Ingredient & Scientific name & Part used & Raw Quantity & $\begin{array}{l}\text { Obtained } \\
\text { Quantity }\end{array}$ & $\begin{array}{l}\text { Quantity taken } \\
\text { for each batch }\end{array}$ \\
\hline $\mathbf{1}$ & Hingula & Cinnabar & - & $750 \mathrm{gm}$ & $828 \mathrm{gm}$ & $170 \mathrm{gm}$ \\
\hline $\mathbf{2}$ & Gandhaka & Sulphur powder & - & $800 \mathrm{gm}$ & $585 \mathrm{gm}$ & $70 \mathrm{gm}$ \\
\hline $\mathbf{3}$ & Tankana & Sodium pyroborate & - & $450 \mathrm{gm}$ & $219 \mathrm{gm}$ & $70 \mathrm{gm}$ \\
\hline $\mathbf{4}$ & Vatsanabha & Aconitum ferox Wall ex seringe & Root & $450 \mathrm{gm}$ & $291 \mathrm{gm}$ & $70 \mathrm{gm}$ \\
\hline $\mathbf{5}$ & Maricha & Piper nigrum Linn & Fruit & $360 \mathrm{gm}$ & $255 \mathrm{gm}$ & $70 \mathrm{gm}$ \\
\hline $\mathbf{6}$ & Pippali & Piper longum Linn & Fruit & $360 \mathrm{gm}$ & $240 \mathrm{gm}$ & $70 \mathrm{gm}$ \\
\hline $\mathbf{7}$ & Ardraka & Zingiber officinale Roscoe & Rhizome & $4200 \mathrm{gm}$ & $3600 \mathrm{ml}$ & $400 \mathrm{ml}$ \\
\hline
\end{tabular}

\section{Preparation of Mrityunjaya Rasa}

All the drugs weighed accurately as shown in table no 2. First purified Vatsanabha and Hingula were placed in mortar and pestle and mixed properly. Then purified Gandhak and Tankan were mixed and finally fine powder of Marich and Pippali were added and mixed thoroughly. Ginger juice was added to untill the mixture immersed completely. Trituration (Bhavana) was carried out till the mixture gets a semisolid form and dried. The same procedure was followed for the second Bhavana and the third Bhavana. With the mixture of proper consistency tablets of one Ratti size (125 mg) (10) were rolled on a flat surface by the circular motion of palm and dried. Tablets were packed in tightly closed container to protect from light and moisture. The same way all three batches were prepared to develop pharmaceutical standardization and named M1, M2 and M3.

\section{Analytical Study}

This study was intended to generate the basic standards for Mrityunjay Rasa as no pharmacopoeia standards are available for this formulation. Organoleptic characters, physicochemical parameters and microbial specification test were carried out for this formulation.

\section{Antibacterial Study}

Preparation of Soxhlet Extract of Mrityunjay Rasa Solvents used for Soxhlet Extraction of Mrityunjay Rasa (Trial drug) were - A: Benzene, B: Chloroform, C: Ethanol, D: Distilled Water. The Trial drug extracts were named as
A: Benzene Extract, B: Chloroform Extract, C: Ethanol Extract, D: Distilled Water Extract, and E: Streptomycin (Standard drug).

Bacterias: - 1) E-coli (NCIM.2685), 2) Pseudomonas aeurginosa (NCIM2200), 3) Staphylococcus aureus (NCIM.2079). All cultures collected from NCL, Pune are pure, authentic and obtained from standard culture collections like ATCC, NCIB.

\section{Preparation of Nutrient Agar media}

Antibacterial activity which is essential for solidification is performed by using Agar media. The module of Nutrient Agar Media (High media REF 1001) was made by Peptone (1gms), Beef Extract (0.3 gms), Sodium chloride (0.5 gms), Agar (2.5 gms), Distilled water $(100 \mathrm{ml})$ of $\mathrm{pH}$ of the media $7.4 \pm 0.2$

Agar solution of required quantity was prepared in accordance with the standard ratio with $\mathrm{pH}$ 7.2. The prepared media was transferred in four conical flasks which were sealed with aluminium files and sterilized in an autoclave for 15 minutes. Then flasks were poured into the sterile Petri plates and incubated for $37 \pm 20 \mathrm{C}$ for $24 \mathrm{hrs}$.

\section{Preparation of different concentrations of extracts of Mrutyunjay rasa}

Different concentrations of Soxhlet extracts of Mrutyunjay Rasa were prepared by making a suspension in distilled water, as Mrutyunjay rasa is not soluble in water. The $10 \mathrm{mg} / \mathrm{ml}, 15 \mathrm{mg} / \mathrm{ml}$ and $25 \mathrm{mg} / \mathrm{ml}$ concentration of four different Soxhlet extracts of Mrutyunjay rasa were prepared. 


\section{Preparation of Concentration of standard drug}

To test antibacterial activity, Streptomycin was selected as a standard drug and the solvent of this standard drug was prepared at a concentration of $25 \mu \mathrm{g} / \mathrm{ml}$. The solution of the standard drug was prepared in distilled water. The discs were labelled as $\mathrm{S} 1$ and S2 i.e. S1: $50 \mu \mathrm{g} / \mathrm{ml}$ and $\mathrm{S} 2: 100 \mu \mathrm{g} / \mathrm{ml}$.

\section{Preparation of Inoculum Bacterial culture}

The sterile nutrient Agar medium was cooled to $45^{\circ} \mathrm{C}$ and spread with 106 cells $/ \mathrm{ml}$ of respective bacterial culture individually and 5 holes or wells about $9 \mathrm{~mm}$ in diameter were cut in the medium with a sterile cork borer. The discs prepared were labelled as $\mathrm{T} 1, \mathrm{~T} 2$ and $\mathrm{T} 3$ respectively i.e. $\mathrm{T} 1-10 \mathrm{mg} / \mathrm{ml}, \mathrm{T} 2$ $-15 \mathrm{mg} / \mathrm{ml}$ and $\mathrm{T} 3-25 \mathrm{mg} / \mathrm{ml}$ and each labelled discs were again labelled according to ditches made in them as A, B, C, D, E.

\section{Application of different concentration [trial and standard]}

Solvent extract of different concentration of trial drug equivalent to $10 \mathrm{mg} / \mathrm{ml}$ was dropped into four approximate labelled ditch (A, B, C, D), and into the remaining ditch E, Streptomycin $(25 \mu \mathrm{g} / \mathrm{ml})$ was used as a positive control. The same sequence was repeated with $15 \mathrm{mg} / \mathrm{ml}$ and $25 \mathrm{mg} / \mathrm{ml}$ Solvent extract of different concentration of the trial drug. Discs were placed at equidistant. For the identification, names of test strains were specified on the Petri discs and were marked with a marker.

\section{Incubation}

The inoculated plates were placed on the table for 1 hour to allow the extract to diffuse into the agar. The NA plates were incubated aerobically at $37^{\circ} \mathrm{C}$ for $24 \mathrm{hrs}$. Zones of inhibition produced after incubation was measured in millimeteres (11).

\section{Observation and results}

Preparation of Mrityunjay Rasa: The quantity of Ardraka swarasa has not changed significantly and the duration required for Bhawana has increased with subsequent Bhawana. The average quantity of Ardraka swarasa required for one Bhawana was $399.99 \mathrm{ml}$. The average required time duration for one Bhawana was $11 \mathrm{hr} 55 \mathrm{~min}$. An average $145.57 \%$ yield was found after the complete drying of Mrityunjay Rasa. Mrityunjay Rasa with roundshaped tablets was prepared with an average weighing $124 \mathrm{mg}$. The colour of the ingredient powder was bright a reddish which later converted into reddish shade after tablet preparation. Mrityunjay Rasa tablets were having a specific smell. (Table no.3).

Table no.3: Observation during the preparation of Mrityunjay Rasa

\begin{tabular}{|c|c|c|c|c|c|c|c|}
\hline Batches & $\begin{array}{c}\text { Wt. of } \\
\text { Mrityunjaya } \\
\text { Rasa } \\
\text { churna(gm) }\end{array}$ & $\begin{array}{l}\text { No.of } \\
\text { Bhawana }\end{array}$ & $\begin{array}{c}\text { Amount of } \\
\text { Ardraka } \\
\text { Swarasa } \\
\text { required }(m l)\end{array}$ & $\begin{array}{l}\text { Time required } \\
\text { for Bhawana } \\
\text { (hrs) }\end{array}$ & $\begin{array}{l}\text { Total weight of } \\
\text { prepared medicine } \\
\text { after drying(gm) }\end{array}$ & Yield \% & Gain \% \\
\hline \multirow{3}{*}{ M 1} & \multirow{3}{*}{490} & $1 \mathrm{st}$ & 400 & 8 & \multirow{3}{*}{710} & \multirow{3}{*}{144.89} & \multirow{3}{*}{44.89} \\
\hline & & $2 \mathrm{nd}$ & 390 & 12 & & & \\
\hline & & $3 \mathrm{rd}$ & 400 & 16 & & & \\
\hline \multirow[t]{3}{*}{ M 2} & \multirow{3}{*}{490} & $1 \mathrm{st}$ & 400 & 8 & \multirow{3}{*}{700} & \multirow{3}{*}{142.85} & \multirow{3}{*}{42.85} \\
\hline & & $2 \mathrm{nd}$ & 400 & 10 & & & \\
\hline & & $3 \mathrm{rd}$ & 380 & 15 & & & \\
\hline \multirow{3}{*}{ M 3} & \multirow{3}{*}{490} & $1 \mathrm{st}$ & 400 & 8 & \multirow{3}{*}{730} & \multirow{3}{*}{148.97} & \multirow{3}{*}{4,897} \\
\hline & & $2 \mathrm{nd}$ & 400 & 12 & & & \\
\hline & & $3 \mathrm{rd}$ & 430 & 15 & & & \\
\hline Avg & 490 & & 399.99 & 11.55 & 713.33 & 145.57 & 45.57 \\
\hline
\end{tabular}

\section{Analytical study}

The formulation was first tested for Organoleptic parameters such as touch, odour and colour which are shown in table no.4. The physicochemical analysis includes a loss on drying at $105^{0} \mathrm{C}$, Total ash, Acid insoluble ash, Alcohol soluble extractives, Water-soluble extractive and $\mathrm{pH}$. The observation and results for physicochemical tests are shown in table no.5 Microbial specifications were tested to validate its safety and therapeutic use. Table no. 6 shows the results for microbial specification for Enterobacteriaceae, Total fungus count, E-coli, Salmonella, Staphylococcus aureus and Pseudomonas aeruginosa which were performed as per CCRAS parameters.

Table no.4: Organoleptic parameters of Mrityunjay Rasa of all batches

\begin{tabular}{c|c|c|c|}
\hline Parameters & M 1 & M 2 & M 3 \\
\hline Touch & Smooth & Smooth & Smooth \\
\hline Colour & Reddish & Reddish & Reddish \\
\hline Odour & Specific & Specific & Specific \\
\hline
\end{tabular}


Swapnali N Khabade et.al., Pharmaceutico-analytical profile of Mrityunjay Rasa and evaluation of its Antibacterial activity

Table no.5: Physicochemical parameters of Mrityunjay Rasa

\begin{tabular}{|c|c|c|c|c|}
\hline $\begin{array}{l}\text { S. } \\
\text { N. }\end{array}$ & Parameters & M 1 & M 2 & M 3 \\
\hline 1 & $\begin{array}{l}\text { Loss on } \\
\text { drying }(\% \mathrm{~W} / \\
\mathrm{W})\end{array}$ & 2.19 & 2.17 & 2.20 \\
\hline 2 & $\begin{array}{l}\text { Ash Value } \\
(\% \mathrm{w} / \mathrm{w})\end{array}$ & 15.85 & 15.90 & 15.87 \\
\hline 3 & $\begin{array}{l}\text { Acid } \\
\text { insoluble } \\
\text { ash }(\% \text { w/w })\end{array}$ & 2.44 & 2.42 & 2.44 \\
\hline 4 & $\begin{array}{l}\text { Water soluble } \\
\text { extract }(\% \mathrm{w} / \\
\mathrm{w})\end{array}$ & 20.44 & 20.42 & 20.45 \\
\hline 5 & $\begin{array}{l}\text { Alcohol } \\
\text { soluble } \\
\text { extract }(\% \text { w/ } \\
\text { w) }\end{array}$ & 2.29 & 2.30 & 2.28 \\
\hline 6 & $\mathrm{pH}(\% \mathrm{w} / \mathrm{v})$ & 8.5 & 9.0 & 8.7 \\
\hline 7 & Hardness & 3 & 3 & 3 \\
\hline 8 & $\begin{array}{l}\text { Uniformity of } \\
\text { weight }(\%)\end{array}$ & -0.0140 & -0.0145 & -0.01403 \\
\hline 9 & $\begin{array}{l}\text { Disintegration } \\
\text { time }\end{array}$ & $30 \mathrm{~min}$ & $\begin{array}{l}30 \mathrm{~min} \\
30 \mathrm{sec}\end{array}$ & $\begin{array}{l}30 \mathrm{~min} \\
30 \mathrm{sec}\end{array}$ \\
\hline 10 & Particle Size & 95.40 & 95.42 & 95.40 \\
\hline
\end{tabular}

Table no.6: Microbial contamination test of Mrityunjay Rasa

\begin{tabular}{|c|l|l|l|l|}
\hline $\begin{array}{c}\text { S. } \\
\text { N. }\end{array}$ & Parameters & M 1 & M 2 & \multicolumn{1}{|c|}{ M 3 } \\
\hline $\mathbf{1}$ & $\begin{array}{l}\text { Total Plate } \\
\text { Count }\end{array}$ & $49^{*} 10$ & $50 * 10$ & $50 * 08$ \\
\hline & Cfu/g & Cfu/g & Cfu/g \\
\hline $\mathbf{2}$ & $\begin{array}{l}\text { Total Fungal } \\
\text { Count }\end{array}$ & $\begin{array}{l}\text { Cfu/g } \\
\text { Cfu }\end{array}$ & $\begin{array}{l}30 * 08 \\
\text { Cfu/g }\end{array}$ & $\begin{array}{l}30 * 05 \\
\text { Cfu/g }\end{array}$ \\
\hline $\mathbf{3}$ & $\begin{array}{l}\text { Enterobactor } \\
\text { spp. }\end{array}$ & Absent & Absent & Absent \\
\hline $\mathbf{4}$ & $\begin{array}{l}\text { Salmonella } \\
\text { spp. }\end{array}$ & Absent & Absent & Absent \\
\hline
\end{tabular}

Table no.7: Heavy Metals Test of Mrityunjay Rasa

\begin{tabular}{|l|l|l|l|l|} 
Sr.no & Parameters & M 1 & M 2 & M 3 \\
\hline 1 & Lead & BDL & BDL & BDL \\
\hline 2 & Mercury & BDL & BDL & BDL \\
\hline 3 & Arsenic & BDL & BDL & BDL \\
\hline 4 & Cadmium & BDL & BDL & BDL
\end{tabular}

BDL- Below Detectable Level

Table no.8: Assay of Elements of Gandhaka

Before

Batches Elements purification

(\%)

99.65

99.60

99.63
After purification

\begin{tabular}{|l|l|l|l|}
\hline M 1 & Sulphur & 99.65 & 99.70 \\
\hline M 2 & Sulphur & 99.60 & 99.71 \\
\hline M 3 & Sulphur & 99.63 & 99.70 \\
\hline
\end{tabular}

\section{Antibacterial Study}

The results are inferred on the source of readings of the zone of inhibition of specific organisms. The observations were calculated by using Vernier Calipers. In the present study one $\mathrm{G}(+)$ ve organism viz Staphylococcus aureus and two G (-) ve organisms E.coli and Pseudomonas aeurginosa were used to evaluate the antibacterial activity of Mrutyunjay rasa.

Antibacterial activity of respective standard and trial drugs were done in three different concentrations $(10 \mathrm{mg} / \mathrm{ml}, 15 \mathrm{mg} / \mathrm{ml}$, and $25 \mathrm{mg} / \mathrm{ml})$. The antibacterial activity was carried out with 18 Petri plates for each organism and at different extract concentrations.

Table no. 9- Zone of inhibition in $\mathrm{mm}$ of Soxhlet extract of Mrityunjay Rasa samples. (TEST)

S. Antimicrobial Inhibition zones in diameter N. agent (mm)

\begin{tabular}{|l|l|c|c|c|}
\hline & $\begin{array}{c}\text { Extract } \\
\text { concentration }\end{array}$ & $\begin{array}{c}\text { Escheri } \\
\text { chia coli }\end{array}$ & $\begin{array}{c}\text { P. } \\
\text { aeroginosa }\end{array}$ & $\begin{array}{c}\text { Staph. } \\
\text { aureus }\end{array}$ \\
\hline A & $\begin{array}{l}\text { Benzene Extract } \\
-25 \mathrm{mg} / \mathrm{ml}\end{array}$ & $10 \mathrm{~mm}$ & -- & $10 \mathrm{~mm}$ \\
\hline $\mathrm{B}$ & $\begin{array}{l}\text { Choloroform } \\
\text { Extract }-25 \mathrm{mg} / \\
\text { ml }\end{array}$ & $09 \mathrm{~mm}$ & $06 \mathrm{~mm}$ & $18 \mathrm{~mm}$ \\
\hline $\mathrm{C}$ & $\begin{array}{l}\text { Ethanol Extract } \\
-25 \mathrm{mg} / \mathrm{ml}\end{array}$ & $11 \mathrm{~mm}$ & $08 \mathrm{~mm}$ & $16 \mathrm{~mm}$ \\
\hline $\mathrm{D}$ & $\begin{array}{l}\text { Distilled Water } \\
-25 \mathrm{mg} / \mathrm{ml}\end{array}$ & $08 \mathrm{~mm}$ & -- & $20 \mathrm{~mm}$ \\
\hline E & $\begin{array}{l}\text { Streptomycin }- \\
25 \mu \mathrm{g} / \mathrm{ml}\end{array}$ & $11 \mathrm{~mm}$ & $15 \mathrm{~mm}$ & $35 \mathrm{~mm}$ \\
\hline & & & & \\
\hline
\end{tabular}


The results reveal that organisms have shown a mixed response to Mrutyunjay rasa. At $25 \mathrm{mg} / \mathrm{ml}$ concentration, both $\mathrm{G}(+)$ ve and $\mathrm{G}(-)$ ve organisms have shown significant zone of inhibition for Mrutyunjay rasa suggesting its antibacterial activity and in $G(-)$ ve organisms $E$. coli have shown an appreciable zone of inhibition where $\mathrm{P}$. aeruginosa have shown insignificant zone of inhibition for extracts of Mrutyunjay rasa. However compare to the standard drug Streptomycin, Mrutyunjay rasa has also shown antibacterial activity whereas $10 \mathrm{mg} / \mathrm{ml}$ and 15 $\mathrm{mg} / \mathrm{ml}$ concentration of extracts would not show any zone of inhibition.

\section{Discussion}

In Ayurveda herbs and minerals are the major source of drugs for the preparation of medicines. According to the requirement, these drugs are flourished by undergoing varied modulations. This aids the physician for minimum dose, palatability, easy administration, increased shelf life and bioavailability (12-13). Mrityunjay rasa is one such herbo-mineral formulation prepared by various processes. Mrityunjay rasa revitalizes the cells and also used in infectious fever conditions. (14)

\section{Pharmaceutical study}

All the ingredients of Mrityunjay rasa were selected strictly according to classical reference. Minerals drugs were purified before being used in the formulation. Hingula shodhana with ginger juice acts as media that helps to convert rough particles into fine and soft particle form. Due to the continuous trituration (total 7 Bhavana) the fineness of Hingula increased and the shining property was reduced. Weight gain in Hingula powder was observed might be due to the addition of an equal amount of ginger juice to the Hingula powder each time during the shodhana process. At the end colour changes from shiny dark brown to dark red and the mixture has a fragrance of ginger (15).

In Gandhaka shodhana color of Gandhaka before shodhana have light yellowish color but after purification Gandhaka gained bright yellow colour and became very brittle so that it turns in to powder form easily. Gandhaka shodhana explained in all the text by using different media. In the preparation of Mrutyunjay rasa, its shodhana is especially done in the cow's milk as it is having Rasayana action (16). Before shodhana Tankan which was shiny milky white in color and crystal form turned to plane milky white color, light in weight, amorphous, with no any specific smell after shodhan. After trituration, it turns into fine lusterless powder (17). Vatsanabha swells during shodhan due to soaking in cows urine. After drying it reduced in its size possessing the smell of cow's urine (18).

For study, Mrutyunjay Rasa was prepared in khalva yantra along with bhavana of Ardraka swarasa as mentioned in Yogaratnakar. Bhavana is the process by which powders of drugs are ground to a soft mass with liquid media and allowed to dry (19). It is an important Samskara (processing) in which the coarse powder is transformed into a finer state by particle size reduction and leads to developing pharmacotherapeutically potent medicine (20). After the 3 Bhavana process with Ardraka swarasa the final product was reddish in color with $45.57 \%$ weight gain and rendered the Smell of Ardraka.

\section{Analytical Study}

Analysis of any drug should be known before the experiment. In the present study, Mrityunjay Rasa tested for its physical and chemical analysis. Loss on drying is $2.17 \%, 2.19 \%$ and $2.20 \%$ in M1, M2 and M3 respectively which suggests the presence of the negligible amount of moisture in Mrityunjay Rasa. Hence product will not be affected by microorganisms. Mrityunjay Rasa is practically insoluble in water. Total ash is $15.84 \%, 15.90 \%$ and $15.87 \%$ in M1, M2 and M3 respectively which indicates the presence of organic matter in the final product, which may be inherited during the shodhana procedure and some insoluble particles of mineral drugs used in this preparation. Average Acid insoluble ash $2.43 \%$ indicates that a negligible amount is soluble in acid.

Water-soluble contents are 20.44\%, $20.42 \%$ $20.45 \%$ in M1, M2 and M3 respectively which may be due to mineral contents in Mrityunjaya Rasa and nearly the same in all three batches. Alchohol-soluble contents are $2.29 \%, 2.30 \% \& 2.28 \%$ in M1, M2 and M3 respectively revealed insignificant difference nearly the same in all three batches. Compare to herbal preparations, herbo-mineral formulations are having quite higher values of Water-soluble contents and Alchohol-soluble contents due to the presence of mineral drugs like Hingula, Gandhaka and Tankana. $\mathrm{pH}$ may have increased because of the Tankana and Gomutra used for the shodhana of Vatsanabha. Heavy metals are below the detectable level. The present results are congruent with the study conducted by Gehlot et al (21)

As all the batches were prepared by taking necessary hygienic care and utilizing sterilized instruments, thus result of the microbial content study showed total plate count is $50 * 10 \mathrm{Cfu} / \mathrm{g}$ and the total fungal count is $30^{*} 10 \mathrm{Cfu} / \mathrm{g}$ which is considerable since Ayurvedic preparations are processed usually in open areas and can't avoid handling by bare hands. Enterobacter spp. and Salmonella spp. are absent in all the batches.

Shodhita Hingula was analyzed for total mercury and sulphur content. Total mercury and sulphur content estimated in Hingula before purification is $87.11 \%$ and $0.64 \%$ and after purification is 50.28 and $0.51 \%$ respectively. Cinnabar is a mercurial compound that contains more than $95 \%$ of Mercury sulphide. In which sulphide is relatively in a very small amount to the Mercury. Because of that here in the assay of sulphur the percentage may have obtained less (22). Reduction in the assay of \% of Mercury after purification may be due to the reduction in the mercury because of evaporation of Mercury (Dhum gati) while trituration. Mercury has high vapour pressure which causes the evaporation of 
Mercury at normal temperature (23). Purified Sulphur was analyzed for total Sulphur. Total Sulphur content estimated in purified Sulphur was 99.7 and before purification, it was 99.65 . Increased value suggested the purity of Sulphur after purification (Table no 8) (24).

\section{Antibacterial Study}

There are wide variations in susceptibility of different strains of the same species of organisms. Antimicrobial activity is a technique in which the response of an organism to a particular antimicrobial agent can be established. Many methods are employed for the evaluation of the antimicrobial activity of a drug. For the present study "Cup-plate method" was adopted. This technique is simple and relatively inexpensive which makes it still the method of choice for the average laboratory. One $G(+)$ ve (Staphylococcus aureus,) and two G (-) ve bacterias (E-coli, Pseudomonas aeruginosa) were considered for the study. These microorganisms are responsible for the manifestation of the majority of pathological conditions such as gastroenteritis, pyogenic infections, urinary tract infections, wound infections etc. which commonly leads to the condition of Pyrexia. Nutrient agar is used to culture the bacteria is the simple culture media, which is usually preferred because most of the bacteria are easily grown in this media. They tend to have fewer batch-to-batches variations. The growth of organisms was confirmed by the turbidity of the media. Streptomycin is the standard drug selected for antibacterial activities.

As readymade discs were not available in the market, discs were prepared in the laboratory. Mrutyunjay Rasa is insoluble in water. Hence its extracts using four different solvents such as Benzene, Chloroform, Ethanol and Water were used. The residue powder form collected from the extracted solvent was then used for making different concentrations of trial samples. From the respective solvents prepared dosage of $10 \mathrm{mg} / \mathrm{ml}, 15 \mathrm{mg} / \mathrm{ml}$, and $25 \mathrm{mg} / \mathrm{ml}$ concentrations of Mrityunjay Rasa. The standard positive control was concentrated in distilled water as $25 \mathrm{microgram} / \mathrm{ml}$. The first Nutrient agar was incubated for twelve hours. This indicated that it has got no activity against microorganisms. Agar was used as a solidifying agent in microbiological media. It is common for bacterias and it is suitable because it has virtually no nutritive value and is not affected by bacterial growth.

Aseptic care was taken throughout the procedure. Results were studied based on the zone of inhibition. It revealed that the measured zone of inhibition of the Soxhlet extracts of Mrutyunjay rasa has shown a significant maximum zone of inhibition against Staphylococcus aureus at $25 \mathrm{mg} / \mathrm{ml}$ concentration. No zone of inhibition has been observed at $10 \mathrm{mg} / \mathrm{ml}$ and $15 \mathrm{mg} / \mathrm{ml}$ concentration of the Soxhlet extracts of Mrutyunjay Rasa. Antimicrobial activity depends upon the rate of diffusion of the drug through an agar surface. Watersoluble drugs readily diffuse whereas water-insoluble compounds take a relatively longer duration to diffuse through the surface.

\section{Probable mode of action alleviate}

Hingula (Cinnabar) is the main ingredient of Mrutyunjay Rasa. It nullifies Kapha, alleviates diseases caused by Pitta, useful in splenomegaly, skin diseases, poisoning, jaundice, facilitates proper digestion. It also improves the strength intellect and lusture of the body. It alleviates severe rheumatoid arthritis and fever (25). Mrutyunjay Rasa also shows antibacterial property and cures all types of fever. By this, it is evident that the properties of Hingul exist in Mrutyunjay Rasa. Gandhaka is another ingredient of Mrutyunjay Rasa which possesses bactericidal action against $\mathrm{G}(+)$ ve and $\mathrm{G}(-)$ ve organisms. It is insecticidal and acts as an antidote to poisons. It also alleviates pruritus, skin diseases like erysipelas and ringworm and provides strength to the Mercury (26). Aconite destroys tridosha aggravation- especially the vata-kapha disorders, alleviates loss of appetite, cures skin diseases, rheumatoid arthritis, splenomegaly, gout, dyspnoea and improves bioavailability (27). Tankan is added as one of the ingredients in the formulation because it is considered the best antidote to Aconite and hence most of the Aconite containing compounds have Tankana invariably (28). Whereas the herbal drugs Marich is Katu, Tikshna, Dipana, Shwasa and Shula rogahara, and Krumighna. Pippali is having Jwaraghna property and ginger is Ushna, Tikshna, Dipana, Madhur vipaki and Ruksha (29).

Pippali have antipyretic activity marked out in Ayurvedic classics which also has scientific evidence. Piperine, an active constituent of Pippali (Piper longum) \& Marich (piper nigrum) has antipyretic activity produced by a significant reduction in rectal temperature that may be due to inhibitory effect in prostaglandin secretion (30). Piperine is known as a bioavailability enhancer (31).

In Ayurvedic literature Mrityunjay Rasa is told as having Jwaraghna property, it is one of the remedies for all types of fever. Modern science considers bacterial infection as one of the causes of fever or pyrexia. Here present study also proves that Mrutyunjay Rasa is having antibacterial property. So it is obvious that Mrutyunjay Rasa exhibits bacteriostatic action and cures fever.

\section{Conclusion}

Mrityunjay Rasa is a Kharaliya Rasayana and herbo-mineral classical preparation and its pharmaceutical processing is easy and very economical. This yields the expected results during the whole pharmaceutical study on an average of $145.57 \%$ and the average gain obtained is $45.57 \%$. The analytical study also shows within normal limits as compared to the standard parameters. This evaluates its quality of standardization. Mrityunjay Rasa has shown a better zone of inhibition against Staphylococcus aureus. As the antimicrobial results were dose-dependent thus it can be concluded that Mrityunjay Rasa possesses significant antimicrobial activity. 


\section{References}

1. Rathi B, Rajput D, Gokarn R, Mehakarkar D., PharmacoTherapeutic Profile of Laxmivilas Rasa, J Indian Sys Med, 2015; 3(3): 141- 148

2. Rathi B, Rathi R, Pusadkar S. Contribution of the text Rasapaddhati in the history of Indian alchemy: A review. J Indian Sys Med 2019;7:70-4.

3. Sharma D, Mitra S, Rawat S, Sharma KC. Role of Jwaraghani gutika in the management of Jwara. J Convent Knowl Holist Health, 2018, 2 (1): $1-3$

4. Shastri L. Yogaratnakar with Vidyotini Hindi Commentary, Jwarachikitsa, Chaukhmba prakashan, Varanasi,reprint edition 2008; p244

5. Mishra S. Rasaratnasamuchhaya of Acharya shree Vagbhat, edited with Sidhhiprada hindi commentary, chapter $3 / 20$, Chaukhambha Orientalia, 1 st edition, 2011. P 76

6. Mishra S. Rasaratnasamuchhaya of Acharya shree Vagbhat, edited with Sidhhiprada hindi commentary, chapter3/143, Chaukhambha Orientalia, 1 st edition, 2011. P 93

7. Shastri K.(editor). Rasatarangini by Acharya Sadanada Sharma,24th Chapter, Motilal Banarasidas, $11^{\text {th }}$ edition, 1979. P 651

8. Shastri K.(editor). Rasatarangini by Acharya Sadanada Sharma, $13^{\text {th }}$ Chapter, Motilal Banarasidas, $11^{\text {th }}$ edition, 1979. p 318

9. Anonymous, The Ayurvedic Formulary of India Second Edition.Govt of India, The Ministry of Health and Family Welfare, Dept. of Indian systems of Medicine \& Homoeopathy, 2003, Part I, Shodhana, New Delhi. P369

10. Sarkar PK, Das S, Prajapati PK. Ancient concept of metal pharmacology based on Ayurvedic literature. Ancient Science of Life. 2010 Apr; 29(4):1.

11. Pulipati S. A comparative antibacterial study of Ixora coccinea L. plants with red, orange, pink and white flowers. Asian Journal of Pharmaceutical Research and Health Care. 2012; 4(1): 7-10

12. Rathi B, Rathi R, Rajput DS. Pharmaceutical standardization of Avalgujadi Lepaguti. J. Indian Sys Med. 2016;4(2);72-76

13. Rathi B, Rathi R. Pharmaceutical standardization of Bakuchi vati: a modified dosage form of Dhatryadi Yoga. Int. J. Res. Ayurveda Pharm. 2017;8(1):57-61.

14. Sud SS. Brilliance of rasa aushadhi in lifestyle disorders management. Journal of Ayurveda and Holistic Medicine (JAHM). 2015 Jan 15; 2(9):42-6.

15. Gupta D, Koteshwar P, Mitti J, Patil M. Pharmaceutico-Analytical Study of Hinguleshwara Rasa. Rasamruta, June 2012; 4:5

16. Srinivasulu B, Dev PB, Murthy PH. Chemical Characterization of Samaguna Balijarita Kajjali (Black Sulphide of Mercury). International Journal of Pharmaceutical and Phytopharmacological Research. 2017 Mar 16;2(1):16-9.
17. Jibkate BR, Rathi BJ, Wanjari AS, Rajput DS. Critical review on pharmaceutical prospects of acid formulations described in Ayurveda classics with respect to Draavak Kalpas. Journal of Indian System of Medicine. 2019 Jan 1;7(1):33.

18. Nithya VS. A review on need of Vatsanabha (Aconitum ferox) Shodhana and its Pharmacovigilance concern. Journal of Pharmacovigilance \& Drug Safety. 2019;16(2):45-6.

19. Dhote M, Rathi B, Dongre R. Pharmaceutical evaluation of Vidangadi Lepaguti- an Ayurvedic topical formulation. International Journal of Ayurvedic Medicine, 2020: 11(2); 212-217

20. Mahulkar S, Rathi B. Pharmaceutical Standardisation of KukkutandaTvak Bhasma (Incinerated Egg Shell), J. Res. Tradit. Med. 2017; 3(2): 44-49

21. Gehlot A, Sujatha K, Kumar S. Analytical evaluation of Mrityunjaya Rasa. Journal of Ayurveda and Integrated Medical Sciences, 2018 Jan 10;2(6):53-5.

22. Scheiner BJ, Lindstrom RE, Shanks DE. Recovery of mercury from cinnabar ores by electrooxidation. US Department of Interior, Bureau of Mines; 1973.

23. Lindqvist, O. and Rodhe, H., 1985. Atmospheric mercury-a review. Tellus B, 37(3), pp.136-159.

24. Pardeshi K, Kadibagil V, Ganti B. www. ijrap. net, Gandhaka Shodhana (Purification Of Sulphur), IAMJ,2018;6(9):1962-1966

25. Patel Asma,M.Gopi Krishna, J.Shashidhar. A Conceptual Review on Hingula (Cinnabar$\mathrm{Hgs}$ ). International Journal of Ayurveda and PharmaResearch. 2019;7(6):32-39

26. Kasavajjhala S, Prasad JS. Purificatory processes of Gandhaka (sulphur) as described in the medieval indian text Anandakanda International Research Journal Of Pharmacy. 2014: 5 (5);438-443

27. Khurshid S, Amjad MS, Malik KF, Sabir S. Clinical and therapeutic potential of Aconitum heterophyllum. J Coast Life Med. 2015 Dec 10;3(12):1003-5.

28. Shaikh SM, Doijad RC, Shete AS, Sankpal PS; A Review on: Physicochemical evaluation of ayurvedic mineral drug Tankan Bhasma; PharmaTutor; 2016; 4(4); 23-27

29. Damanhouri ZA, Ahmad A (2014) A Review on Therapeutic Potential of Piper nigrum L. (Black Pepper): The King of Spices. Med Aromat Plants 3: 161. doi: 10.4172/2167-0412.1000161

30. Khushbu, C., Roshni, S., Anar, P., Carol, M. and Mayuree, P. Phytochemical and therapeutic potential of Piper longum Linn a review. International journal of research in Ayurveda and pharmacy, 2011; 2(1):157-61.

31. Sabina, E.P., Nasreen, A., Vedi, M. and Rasool, M., 2013. Analgesic, antipyretic and ulcerogenic effects of piperine: an active ingredient of pepper. Journal of Pharmaceutical Sciences and Research, 5(10), p.203. 